Kirja-arvio

\title{
Kaupunkitarinoiden vaarat
}

\author{
Arhipova, Aleksandra ja Anna Kirzjuk. 2020. Opasnye sovetskie veštši. Gorodskie \\ legendy i strahi v SSSR. Moskova: Novoe literaturnoe obozernie. 536 sivua.
}

\author{
Karina Lukin
}

$\mathrm{N}$ euvostoliiton kansalaisten arkisen elämän ja ajattelun hahmottaminen ulkopuolelta tai jälkikäteen on tutkimukselle haaste, jonka antropologit ja sosiologit ovat ottaneet rohkeasti vastaan selvitellessään esimerkiksi asumiseen tai kuluttamiseen liittyviä käytänteitä. Ihmisten arjen uskomuksia ja niihin liittyvää käyttäytymistä on tutkittu vähemmän, mikä ilmiselvästi johtuu siitä, että sopivaa tutkimusaineistoa ei ole ollut käsillä. Moskovalaisten folkloristien Aleksandra Arhipovan ja Anna Kirzjukin teos, jonka nimi suomentuu Vaarallisia neuvostoasioita, pureutuu juuri näihin uskomuksiin. Tutkimus keskittyy neuvostoaikaisiin nykytarinoihin, joita Venäjällä kutsutaan kaupunkitarinoiksi (gorodskie legendy). Teos on äärimmäisen arvokas neuvostoarjen kuvaus, sillä se ei pysähdy aineistonsa mustavalkoiseen kuvaan, vaan tarjoaa laajoja ja syviä historiallisia ja kulttuurisia taustatietoja ja metodologisia keskusteluja

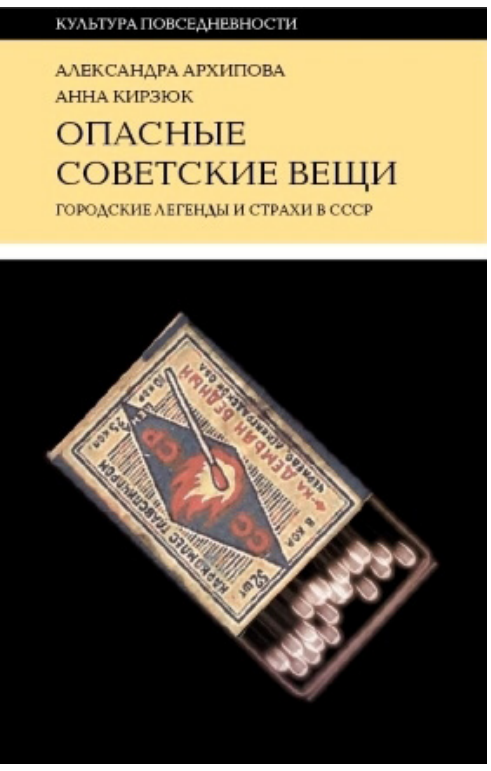
pohdintojensa rinnalle. Lukija saa oppia perinteen aihelmien kansainvälisyydestä samalla, kun niiden neuvostoliittolainen erityisyyskin avautuu. Kerronnan kietoutuminen valtaan, tietoon, niiden puutteeseen ja epävarmuuteen siivittävät tutkimuksen kulkua, ja teemat jäävät sopivasti kihelmöimään takaraivoon.

Tutkimusaiheena nykytarinat ovat äärettömän kiehtovia, mutta arkipäiväisyytensä, lyhyen muotonsa ja epätotuudenmukaisuutensa vuoksi niihin ja niiden tutkijoihin voi kohdistua väheksyntää, mikä tulee esille jo kirjan esipuheessa. Arhipova ja Kirzjuk vähät välittävät väheksyjistä: heidän folkloristiikalle tyypillinen näkökulmansa ei ole kiinnostunut tarinoiden estetiikasta tai totuusarvosta, vaan kirjassa pohditaan kertomusten merkityksiä inmisten arkisessa elämässä. Kirjassa ei keskitytä yksittäisiin kertojiin ja kertomistilanteisiin, vaan siinä tarkastellaan yleisellä tasolla ympäri Neuvostoliittoa arkistoitujen kertomusten sisältöjä, niiden toistuvuutta kerronnan ulkopuolella ja niiden vaikutusta ihmisten toimintaan. 
Opasnye sovetskie veštši alkaa erinomaisella johdannolla nykytarinoiden tutkimukseen. Arhipova ja Kirzjuk esittelevät niin aiempaa kuin tämänpäiväistä, paljolti sosiaalisen median mekanismeihin keskittyvää kirjallisuutta. Johdanto kattaa folkloristiikan ja antropologian lisäksi myös sosiaalipsykologista ja sosiologista tutkimusta. Kirjan lähtökohdaksi piirtyy ilahduttavan avara näkemys, jonka puitteissa nimenomaan lyhyt muoto ja tunnepitoisuus selittävät usein uskomattomien tarinoiden liikkumista ja lopulta myös niiden vaikutusta ihmisten toimintaan. Kirjoittajat nimittävät moraaliseksi paniikiksi mekanismia, jonka puitteissa yhteiskunnallisten ongelmien laajan käsittelyn ja analyysin sijaan keskitytään etsimään yksinkertaisia syitä tai syntipukkeja: esimerkiksi potilaitaan myrkyttävistä juutalaislääkäreistä kertova nykytarina levisi ennen vain Neuvostoliiton reunamilla (Vilnassa), mutta valtaapitävät ottivat sen käyttöönsä vuonna 1953, kun yhdeksää lääkäriä syytettiin puolueen johdossa olevien henkilöiden murhista. Aikanaan paljon kohua herättänyt ja kaupunkitarinoiden liikkumista edistänyt "lääkärien tapaus" oli osa Stalinin laajempaa antisemitististä kampanjaa, jonka puitteissa syytettiin juutalaisia läntisistä yhteyksistä ja porvarillisista salaliitoista. Stalinin kuoleman jälkeen lääkärit vapautettiin syytteistä, mutta neuvostokansalaiset välttelivät vielä pitkään juutalaisia lääkäreitä.

Koronapandemia on tarjonnut hedelmällisen alustan nykytarinoille syntyä ja uudistua, ja Aleksandra Arhipovalla on ollut vientiä myös venäläisessä mediassa. Silti pelkästään korona ei selittäne kirjan jo nyt saamaa arvostusta - se muun muassa sai arvostetun, venäjänkieliselle tietokirjallisuudelle vuosittain jaettavan Libmissija-palkinnon. Arhipova ja Kirzjuk ovat onnistuneet myös tekemään oivaltavia havaintoja, jotka eivät kosketa ainoastaan neuvostomenneisyyttä, vaikka neuvostoajat ovat kirjan ydintä. Se kertoo, niin kuin ihmisten kertoman tutkimus vain voi tehdä, mistä inmiset puhuivat, mitä he pohtivat, mitä pelkäsivät ja millaisia vaikutuksia kaikella tällä on ollut epävirallisessa ja virallisessa neuvostoelämässä, sodassa ja rauhassa, kirjallisuudessa, populaarikulttuurissa ja lasten ja aikuisten toimissa.

\section{Tulkintoja vaarasta, vaarallisia tulkintoja}

Varsinainen analyysi alkaa luvusta kaksi, jossa esitellään vaarallisia merkkejä, tai paremminkin tulkintoja, jotka näkevät vaaran joka paikassa tai missä tahansa. Analyysin taustalla on ajatus siitä, että merkkien tulkinnasta tulee hypersemioottista tilanteissa, joissa ihmiset kokevat huolta tai uhkaa eikä heillä ole selkeää käsitystä siitä, miten he voivat vaikuttaa tapahtumien kulkuun. Hypersemioottisella viitataan yhteisölliseen käytäntöön, jossa merkeistä aletaan tulkita salattuja, piilotettuja merkityksiä, ja kirjoittajat korostavat, että vastaavaa ylitulkintaa on tapahtunut jo ennen Neuvostoliittoa ja neuvostoyhteyksien ulkopuolellakin. Analyysi kuvaa vakuuttavasti yhtäältä sen, miten hypersemioottisuus syntyi neuvostokoneiston omissa käytänteissä, etenkin suuren terrorin myötä, jolloin kansanvihollisia alettiin etsiä kaikkien ja kaiken keskuudesta. Siellä, mihin piirrettiin roihuava kolmiliekkinen aatteen tuli, nähtiinkin kyrillinen T, 3 ja Ш, mikä tulkittiin lyhenteeksi trotskilais-zinovjevilaisesta koplasta. Pahaksi onneksi symboli oli nuorisojärjestö Komsomolin kravattisormuksessa, jota vielä vuosikymmentenkään kuluttua ei suostuttu käyttämään, vaikka puolue koetti hiljentää itse nostamansa epäilyt. Luvun ytimessä onkin näyttää, miten stalinistinen vainoharhainen merkkien tulkinta alkoi elää ihmisten tavoissa tulkita kuvia, esineitä ja rakennuksia ja millaista kerrontaa se synnytti.

Ensimmäistä analyysia edeltää pitkä johdanto, ja kaikissa seuraavissakin analyysiluvuissa on oma johdantonsa. Kirja ei johdata lukijaa ainoastaan kerrontaan vaan siihen kokonaiseen yhteiskunnalliseen ja historialliseen taustaan, jossa motiivit kiertävät ja muuntuvat. 
Siksi Opasnye sovetskie veštši on myös johdanto Neuvostoliiton historiaan: perinnettä ei voi ymmärtää, ellei tiedä, millainen oli stalinilainen merkitysten vakauteen kiinnittyvä yhteiskunta ja miten suojasää vaikutti propagandakoneiston toimintaan tai millaisia vaikutuksia 1970- ja 1980-lukujen avautumisella oli. Muutokset vaikuttivat myös nykytarinoiden elämään ja niiden kertojiin ja kuulijoihin. 1930-luvun Neuvostoliitossa tarinoita pidettiin yhteiskuntaa vahingoittavina ja niiden kertojia kansanvihollisina, minkä vuoksi folkloren kertominen saattoi johtaa jopa vankileirituomioon. Suuri muutos tapahtui 1960- ja 1970-lukujen aikana, jolloin juoruilijoita alettiin pitää vihollisen tahattomina apulaisina ja mikä olennaisempaa, hallinto alkoi itse käyttää kaupunkitarinoita hyväkseen. Arhipova ja Kirzjuk nimittävät agit[aatio]tarinoiksi (agitlegenda) kertomuksia, joita levitettiin vaikka kouluissa ja nuorisojärjestö Komsomolissa. Esimerkiksi Moskovan olympialaisten alla alettiin eritoten lapsia varoitella olemasta yhteydessä ulkomaalaisten kanssa. Jos he olisivatkin, heidän ei tulisi ottaa vastaan minkäänlaisia lahjoja, ei varsinkaan purukumia tai konvehteja. Sillä - kuten tarinoiden sairastuneet lapset tai heidän neuvokkaiden äitiensä tekemät löydöt todistavat - purukumi voi olla myrkytetty tai karkkeihin voi olla piilotettu lasimurskaa, neuloja, partakoneenteriä.

\section{Erottelut ja kerronta}

Kirjan vaarallisuuteen viittaava nimi alkaa hahmottua oman ja vieraan rajanvedon kautta. Arhipova ja Kirzjuk hyödyntävät myös Mary Douglasin (2000) teoriaa puhtaasta ja likaisesta. Erottelut toimivat ja auttavat tutkijoita keskittymään monisisältöisen ja lähes koko 1900-luvun Euroopan ja kylmän sodan historiaa halkovan tematiikan haastavassa kokonaisuudessa. Esimerkiksi neljännessä luvussa käsitellään lännessäkin hyvin tunnettuja valmisruokaan liittyviä aiheita, joissa makkarasta löytyy rotanhäntiä ja niin edelleen. Nämä rinnastetaan nälänhädän aikoina levinneisiin ihmissyöjätarinoihin, jotka muun muassa kertovat, mistä inmislihaa syövän tunnistaa, ja toisen maailmansodan aikaiseen sotasaaliiseen, saksalaisten juutalaisista tekemään saippuaan. Rinnastuksen avulla kirjoittajat onnistuvat tuomaan esiin nykytarinoiden taustalla olevien erottelujen keskeisyyden kriisiaikoina ja niiden ulkopuolella.

Kulutustavaroihin liittyvien uhkien jälkeen kirjassa siirrytään käsittelemään kerrontaa, joka keskittyy luokaltaan tai etnisyydeltään toisten aiheuttamiin lääketieteellisiin uhkiin. Luvun taustalle on kirjoitettu kuvaus kemiallisista aseista 1900-luvun alun maailmansodissa. Sen mukaan huhuja toisten valtioiden kemiallisista aseista käytettiin oikeuttamaan omia sotatoimia. Analyysissa kerrotaan Neuvostoliiton ystävyysvaltioista tulleista vaihto-opiskelijoista ja heidän usein eriväristen kehojensa vaarallisuudesta tarinoissa. Lisäksi kerrotaan esimerkiksi länsimaisten turistien kantamista viruslähetyksistä. Näissä kertomuksissa tulee Suomikin mainituksi: suomalaisten vodkaturistien tiedetään heittelevän bussin ikkunoista koeputkia, jotka sisältävät aivokuumetta aiheuttavia viruksia tai bakteereja. Suomalaisia vodkaturisteja ei sen sijaan mainita kirjassa esitellyissä tarinoissa, joissa länsimaiset vieraat antavat tai kauppaavat tauteja aiheuttavia farkkuja, sukkahousuja ja purukumeja. Tämä suomalaislukija muistaa kuulleensa vodkaturistien juttuja juuri edellä mainituista tuotteista - sen sijaan koeputkista ei ole tainnut olla tällä puolen rajaa puhetta. Kemiallisten aseiden viholliskuvien kautta analyysissa rakentuu laaja kaari, joka selittää osin myös ulkomaalaisiin liittyvien uskomusten uskottavuuden neuvostokontekstissa.

Kirjan kaupunkitarinat ovat pääosin varoittavia, ja ne kertovat, miten uhan voi välttää kokonaan tai miten sen kohdatessaan tulisi toimia. Kerronnan taustalle piirtyy toistuvasti sama selitys: tiedon rajallinen määrä ja kokemus siitä, ettei pysty hallitsemaan ympärillä tapahtuvaa, 
synnyttävät viholliskuvia kerrontaan. Kun vihollisen valta tai teknologinen osaaminen on ylivoimaista, tarinat korostavat vihollisen antamia lahjoja ja pyrkimystä luottamukseen. Sen sijaan alemmassa asemassa oleva toinen, kuten mustaihoiset vaihto-opiskelijat, kuvataan vaaralliseksi kokonaisuudessaan ja itsessään, minkä vuoksi heitä olisi parempi välttää kaikin puolin. Kerronnan suosion taustalla Arhipova ja Kirzjuk näkevät niin sanotun ostensiivisen latauksen, joka pohjaa Déghin ja Vazsonyin (1983) teorioihin. Teoksen teorian mukaan toimintaan johtavan nykytarinan tulee olla tunnistettava, kiteytynyt ja tarpeeksi ytimekäs, mutta sen kertojan ja kuulijan on myös pidettävä tarinaa sillä tavoin uskottavana, että se muuttaa hänen käyttäytymistään. Ymmärtääkseni latauksella kirjoittajat viittaavat siihen, että se voi mahdollisesti purkautua ja aiheuttaa laajempaa hätääntymistä, moraalista paniikkia, kuten kirjassa asiaa nimitetään.

\section{Nykytarinoiden elämä nykytarinoiden ulkopuolella}

Ostensiivinen lataus selittää motiivien mahdollista uusiutumista, mutta kirja ei oikeastaan keskity tähän. Se käy laajasti läpi motiivien mahdollisia taustoja ja sitä, miten epävirallinen ja virallinen pallottelevat niitä. Siksi tutkimus osoittaa todella hienosti, miten perinne El elä vain sen tunnistettavassa, kiteytyneessä ja ytimekkäässä muodossa, vaan toisintuu, muokkautuu ja tulee kiistetyksi tai naurunalaiseksi vaihtelevissa konteksteissa eri tavoin. Surullista tarinaa tästä kertoo esimerkiksi mustan Volgan, neuvostoaikana eliittiin ja turvallisuuspalveluun liitetyn auton ympärille muotoutunut kerronta. Musta Volga on suuren terrorin symboli: 1930-luvulla kerrottiin, miten se vei ihmisiä, joista ei sittemmin kuultu. Toisissa tarinoissa pahamaineisen NKVD:n johtajana toimineen Lavrenti Berijan kerrottiin maanittelevan nuoria tyttöjä autoonsa. Mikäli nämä eivät suostuneet sukupuoliyhteyteen, heidän vierelleen asetettiin kukka-asetelma, jonka kysyttäessä kerrottiin tulevan heidän haudalleen. 1970- ja 1980-luvuilla lasten keskuudessa taas kiersi tarina mustasta autosta, joka oli epämääräisellä tavalla vaarallinen. Arhipova ja Kirzjuk selittävät, miten julkinen hiljaisuus tai vaillinainen puhe suuresta terrorista synnytti lasten kerrontaan tarinan, jota voitiin kertoa ja jonka välityksellä purettiin 1930-luvun kauhuja julkisesti.

Ajallisen ja sukupolvien välisen liikkeen hahmottamisen lisäksi tutkimuksessa tuodaan esiin, miten perinnettä on mahdotonta hallita tai pitää sammiossa: se vuotaa, muuntelee itseään ja löytyy mitä inmeellisimmistä yhteyksistä. Nykytarinoiden motiivit ovat eläneet esimerkiksi neuvostoelokuvissa tai samizdat-kirjallisuudessa sekä huumorissa. Kirjan viimeinen analyysiluku keskittyy ydinsodan uhkaan ja sen ympärillä esiintyvään kansanomaiseen luovuuteen. Luku ei onnistu pitäytymään itse nykytarinoissa mutta onnistuu hienosti näyttämään, miten sodan uhkaa käsiteltiin omasta ja vastustajankin näkökulmasta esimerkiksi erilaisissa lauluissa.

Erinomaisia ovat huomiot, joissa kerrotaan, miten neuvostokoneisto löytää kaikkien hallintayritysten jälkeen edestään uuden tai väärin kerrotun tai koneistolle ilkkuvan motiivin. Ilahduttava on myös vitsi, jossa kuvitteellisessa propagandakoneistossa istuvien miesten kuullaan nauravan hillittömästi, koska he olivat keksineet niin hyvän kaupunkitarinan, että voisivat huomenna antaa siitä viiden vuoden tuomion. 


\section{Kirjallisuus}

Dégh, Linda ja Andrew Vázsonyi. 1983. “Does the Word 'Dog' Bite? Ostensive Action: A Means of Legend Telling." Journal of Folklore Research 20: 5-34.

Douglas, Mary. 2000. Puhtaus ja vaara: ritualistisen rajanvedon analyysi. Tampere: Vastapaino.

Folkloristiikan dosentti Karina Lukin on kiinnostunut neuvostoaikaisesta suullisesta ja kirjallisesta perinteestä. 